\title{
Gratifications Derived From Involvement in Organization, Study Habits, and Academic Performance of Students at Naval State University-Main Campus
}

\author{
Christopher Rotilles Vicera, Grace Laude Concepcion \\ College of Education, Naval State University-Main Campus, Naval, Biliran, Philippines
}

\begin{abstract}
This study intended to find out the involvement in organization, study habits and academic performance of students of Naval State University. A total of 88 student respondents are involved in this study with $62.50 \%$ females who are dominating the involvement of students in an organization, most of the respondents are coming from Bachelor of Secondary Education with $87.50 \%$. Majority of the students are first Year College with 63.64\% and majority are Roman Catholic with 90.91\%. Students who are members of the organization in the university are supported with scholarship and the organization of the university are registered by the Student Affairs Office, most of this organization are academic in nature with $98.86 \%$, some active members of these organization are working students. Study habits of the student's respondents are basically depends on their schedule of activities, meetings and other extracurricular events of the University. The academic performance of the student respondents reveals that most of the students answer "Good" with highest indicator of $70.45 \%$. Students who are involved in extracurricular activities like joining the organization could also be a crucial in attaining good scholastic standing. Students must have their proper time management so that they will not overlook some of their duties as students in the University.
\end{abstract}

Key Terms: Gratification; Study Habits; Students Involvement; Academic Performance

\section{Introduction}

School has always been regarded as an avenue to facilitate human aspirations. One of the leading traits of the Filipino family is its love for education; as a panacea to various social and economic problems. With this premise, the school has its gigantic task to make sure these aspirations are met. Students develop their specific skills, their career path which is important to the success of their job in the future happened in the school. With this, students have great opportunities to improve their leadership and interpersonal skills while also increasing their self-confidence. Extracurricular involvement allows students to link academic knowledge with practical experience, thereby leading to a better understanding of their own abilities, talents and career goals. Future employees seek individuals with these increased skills levels, making these involved students more viable in the job market. Specifically, participation in extracurricular activities and leadership roles in these activities are positively linked to attainment of one's first job and to managerial potential.

Students of the University are informed of the various academically related organizations and college based organizations in which students can joined and be affiliated. College life can be stressful, although it is undoubtedly one of the best memorable experiences in one's life. It represents a critical development period of the both late adolescence and young adults.

Based on our observation, the students are obliged to join the college based organizations and in some academic organizations, some members quit in just a short period of time however, some members are still active in their respective organization even if they are already a graduate. The question is how a student strikes a balance between stressful academic subjects and being a member of academic organizations.

\author{
Objectives of the study \\ 1. To determine the demographic profile of the respondents in terms of; \\ 1.1 Sex \\ 1.2 Year Level \\ 1.3 Course \\ 1.4 Religion \\ 1.5 Economic Status \\ 1.6 Level of Involvement \\ 1.6.1 Active \\ 1.6.2 In active \\ 2. To find out the profile of school organizations in terms of; \\ 2.1 Nature
}


2.2 Years of Experience

2.3 Registered by Student Affairs Office

2.4 Incentives

2.5 Number of members

3. To ascertain the level of students involvement in organization;

4. To determine the study habits of the respondents;

5. To determine the respondents academic performance;

6 . Find out the relationship of respondents in terms of;

6.1 Students profile

6.2 Involvement in organization

6.3 Study habits

6.4 Academic performance

\section{Theoretical Framework}

This research is anchored on heuristic approached of Uses and Gratification Theory (UGT) by Katz, Blumler, and Gurevitch synthesized that UGT's approach was focused on the social and psychological origins of needs, which generate expectations of the mass media or other sources, which lead to differential patterns of media exposure, resulting in need gratification and other consequences, perhaps mostly unintended ones. The components of this theory comprises the audience is conceived as active; much initiative in linking gratification and media choice; media compete with other sources of satisfaction; goals of mass media can be derived from data supplied by individual audience and value judgments about the cultural significance of mass communication should be suspended while audience orientations are explored on their own terms. UGT's approach to understanding why and how people actively seek out specific media to satisfy specific needs. It also on audience-centered approach to understanding mass communication. West, 2007. Diverging from other media effect theories that question "what does media do to people?", UGT focuses on "what do people do with media?"

\section{Conceptual Framework}

The conceptualization of this study basically revolves around the student's involvement in organization, study habits and academic performance. Thus, the study is focused on (1) determining the demographic profile of the respondents in term of the following: sex, year level, course, religion, economic status, and level of involvement of the students whether they are actively involved in an organization or inactively involve; (2) find out the profile of the school organizations in terms of the following: nature, years of experience, registration of the organization to student affairs office, incentives and number of members in the organization; (3) ascertain the level of students involvement in organization; (4) determining the study habits of the respondents; (5) determining the respondents academic performance; (6) find out the relationship of respondents in terms of the following: students profile, involvement in organization, study habits and academic performance.

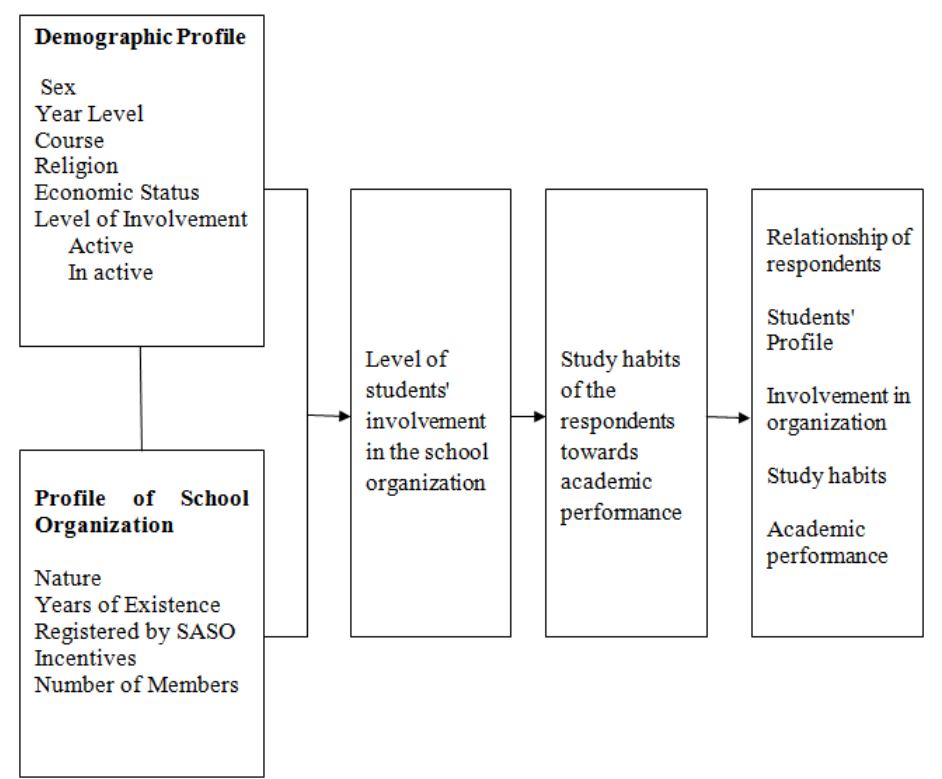

Figure 1 Conceptual Framework of the study 


\section{Methodology}

This research investigation aims to ascertain the involvement of students in organization, performance and gratification of student's of naval State University. The findings can serves as inputs for extracurricular involvement in scholarship and leadership development. A self-constructed questionnaire and rating scales will be utilized in this study. The data obtain will be analyzed using the Ordered Log it Regressions. The study will follow the descriptive survey research design. The findings of this study will be beneficial to the following stakeholders and administrator of Naval State University, the results can provide insights on how the extracurricular activities of the students can be a good input for them to become well-rounded individual. The teachers and administrators could likewise gain useful inputs to improve instructional practices and guidelines that would ensure college students' steeped with knowledge and skills.

Table 1. Distribution of Respondents of the Study

\begin{tabular}{|l|l|}
\hline Name of Organization & Members \\
\hline Estudios Sociales Sociodad & 18 \\
\hline Science Enigma & 16 \\
\hline Language and Literature & 16 \\
\hline Math Enthusiasts & 14 \\
\hline MAPHE Circle & 13 \\
\hline MarCO & 3 \\
\hline Civil Engineers & 3 \\
\hline Lay Movement & 2 \\
\hline Project Alpha & 2 \\
\hline Campus Mission & 1 \\
\hline Total & $\mathbf{8 8}$ \\
\hline
\end{tabular}

\section{Results And Discussion}

This chapters presents the results of the survey, organized and presented on the order by which they address the stated objectives of the study: demographic profile of the respondents, profile of school organizations, level of students involvement in organization, study habits of the respondents, respondents academic performance and relationship of respondents.

\section{Socio-demographic Profile}

The socio-demographic characteristics of the respondents that were considered in this study included sex, year level, course, religion, economic status, and level of involvement.

Table 2. Socio-demographic characteristics of the respondents

\begin{tabular}{|c|c|c|}
\hline Variables & Frequency & Percent $(\mathrm{N}=88)$ \\
\hline \multicolumn{3}{|l|}{ Sex } \\
\hline Male & 33 & $37.50 \%$ \\
\hline Female & 55 & $62.50 \%$ \\
\hline \multicolumn{3}{|l|}{ Year Level } \\
\hline First Year & 56 & $63.64 \%$ \\
\hline Second Year & 24 & $27.27 \%$ \\
\hline Third Year & 8 & $9.10 \%$ \\
\hline \multicolumn{3}{|l|}{ Course } \\
\hline BSED & 77 & $87.50 \%$ \\
\hline BSHRM & 3 & $3.41 \%$ \\
\hline BEED & 2 & $2.27 \%$ \\
\hline AMT & 3 & $3.41 \%$ \\
\hline BSIT & 3 & $3.41 \%$ \\
\hline \multicolumn{3}{|l|}{ Religion } \\
\hline Roman Catholic & 80 & $90.91 \%$ \\
\hline Born Again Christian & 2 & $2.27 \%$ \\
\hline CJLDS & 2 & $2.27 \%$ \\
\hline Jehova's Witnesses & 2 & $2.27 \%$ \\
\hline Seventh Day Adventist & 2 & $2.27 \%$ \\
\hline \multicolumn{3}{|l|}{ Economic Status } \\
\hline Average & 60 & $68.18 \%$ \\
\hline Middle Class & 17 & $19.32 \%$ \\
\hline Poor & 9 & $10.23 \%$ \\
\hline Low Class & 2 & $2.27 \%$ \\
\hline \multicolumn{3}{|l|}{ Level of Involvement } \\
\hline Active & 79 & $89.77 \%$ \\
\hline Inactive & 9 & $10.23 \%$ \\
\hline
\end{tabular}


It could be gleaned from table 2 on the socio-demographic profile that out of 88 respondents 33 are males and 55 are females; on the year level of the respondents 56 are first year, 24 are second year and 8 are in their third year in college; for the course of the respondents majority of are coming from the BSED with $87.50 \%$; for the religion majority of the students respondents are roman catholic with $90.91 \%$. On the economic status $68.18 \%$ are coming from the average class while $19.32 \%$ are middle class, $10.23 \%$ are coming from poor class and $2.27 \%$ are coming from low income class. On the level of involvement 79 or $89.77 \%$ of the respondents are active in the organizations while 9 or $10.23 \%$ are inactive. It could be implied that females are dominating the involvement of students ain an organization, most of the respondents are coming from Bachelor of Secondary Education they roman catholic and more of them are first year college.

\section{Profile of Membership in Organization}

Table 3. Profile of Membership in Organization

\begin{tabular}{|l|l|l|}
\hline Variable & Frequency & Percent $(\mathbf{N}=\mathbf{8 8})$ \\
\hline Nature & & \\
\hline Academic & 87 & $98.86 \%$ \\
\hline Profound & 1 & $1.14 \%$ \\
\hline Year of Existence & & \\
\hline 12 years & 40 & $45.45 \%$ \\
\hline 6 years & 20 & $22.73 \%$ \\
\hline 7 years & 13 & $14.77 \%$ \\
\hline 9 years & 15 & $17.04 \%$ \\
\hline Registered by SASO & & \\
\hline Yes & 87 & $98.86 \%$ \\
\hline NO & 1 & $1.14 \%$ \\
\hline Incentives & & \\
\hline Scholarship & 88 & $100 \%$ \\
\hline Number of Members & $\mathbf{4 5 1}$ & \\
\hline
\end{tabular}

Table 3 reveals out that of 88 students respondents 87 or $98.86 \%$ of the organization of the university are found to be academic, while on the years of existence of the different organization, $45.45 \%$ of the organization stay in the university are 12 years, $22.73 \%$ are six years, $14.77 \%$ are seven years and $17.04 \%$ are 15 years in the university. Of the registered organizations almost of the organization are registered with $98.86 \%$. The incentives of all the organization in the university is a scholarship to all student respondents and summing all members of the organization in the university are 451 students. The date gathered implied that students who are members of the organization in the university are supported with scholarship and the organization of the university are registered by the Student Affairs Office and most of this organization are academic in nature.

\section{Student's involvement in organization}

Table 4. Student's involvement in organization

\begin{tabular}{|l|l|l|}
\hline Variable & Frequency & Percent (N=88) \\
\hline Status of Involvement & 79 & \\
\hline Active & 9 & $89.77 \%$ \\
\hline Inactive & & $10.23 \%$ \\
\hline Reason for Inactivity & 2 & \\
\hline Too much course work & 4 & $2.27 \%$ \\
\hline Employment & 3 & $4.55 \%$ \\
\hline Athlete & & $3.41 \%$ \\
\hline Rating of Experience & 1 & \\
\hline Poor & 3 & $1.14 \%$ \\
\hline Fair & 30 & $3.41 \%$ \\
\hline Good & 31 & $34.09 \%$ \\
\hline Very Good & 23 & $35.23 \%$ \\
\hline Excellent & - & $26.14 \%$ \\
\hline Unfamiliar with any clubs & & - \\
\hline No. of Times attended meetings & 0 & \\
\hline 1 & 4 & - \\
\hline 2 & 6 & $4.55 \%$ \\
\hline 3 & 8 & $6.82 \%$ \\
\hline 4 & 14 & $9.09 \%$ \\
\hline 5 & 56 & $15.91 \%$ \\
\hline $6+$ & & $63.64 \%$ \\
\hline Students Organization & 18 & \\
\hline Estudios Sociales Sociodad & 16 & $20.45 \%$ \\
\hline Science Enigma & 16 & $18.18 \%$ \\
\hline Language and Literature & 14 & $18.18 \%$ \\
\hline Math Enthusiasts & & \\
\hline
\end{tabular}


Gratifications Derived From Involvement In Organization, Study Habits, And Academic...

\begin{tabular}{|l|l|l|}
\hline MAPHE Circle & 13 & $14.77 \%$ \\
\hline MarCO & 3 & $3.41 \%$ \\
\hline Civil Engineers & 3 & $3.41 \%$ \\
\hline Lay Movement & 2 & $2.27 \%$ \\
\hline Project Alpha & 2 & $2.27 \%$ \\
\hline Campus Mission & 1 & $1.14 \%$ \\
\hline No. meetings normally attended & & \\
\hline 1-2 meetings & 15 & $17.05 \%$ \\
\hline 3-5 meetings & 14 & $15.91 \%$ \\
\hline 6-8 meetings & 51 & $57.95 \%$ \\
\hline 9+ meetings & 8 & $9.09 \%$ \\
\hline
\end{tabular}

As gleaned in Table 4, 89.77\% of the student respondents are active member in any organization, $4.55 \%$ answered inactive reason for the they working students, $35.23 \%$ of the respondents are "very good in their rating of experience, $63.64 \%$ of the students attended meetings more than six times, majority of the student respondents members of the organizations are coming from E studios Socials Socio dad (ESS) with $20.45 \%$ and on the number of meeting normally attended by the students is on 6-8 meetings with $57.95 \%$ It can be implied that student organization lasted for years because student respondents even though they working student but still they active in their involvement in the organization.

\section{Study Habits}

For the study habits of the students respondents, each activities was rate on the amount of time they spent on each activity and each question was rated on a scale from one to four: (1) almost never, (2) less than haft the time, (3) more than haft the time and (4) almost always.

Table 5. Questionnaire \# 1 Study Habits of the Respondents

\begin{tabular}{|l|l|l|}
\hline Statements/Indicator & Frequency & Percent (N=88) \\
\hline Do you study outside of class each day? & 52 & $59.09 \%$ \\
\hline Do you keep up to date in your assignments? & 43 & $48.86 \%$ \\
\hline Do you review regularly what was covered in each course? & 31 & $35.23 \%$ \\
\hline $\begin{array}{l}\text { Do you write down all assignments for each class in a special } \\
\text { section of the notebook? }\end{array}$ & 38 & $43.18 \%$ \\
\hline Do you survey a chapter before reading it in detail? & 50 & $56.82 \%$ \\
\hline $\begin{array}{l}\text { As you read an assignment, do you have in mine questions that you } \\
\text { are actually trying to answer? }\end{array}$ & 53 & $60.23 \%$ \\
\hline $\begin{array}{l}\text { Do you try to get the meaning of important new terms as you read } \\
\text { the chapter? }\end{array}$ & 46 & $52.27 \%$ \\
\hline Do you recite to yourself at the end of each section of the chapter? & 47 & $54.02 \%$ \\
\hline $\begin{array}{l}\text { Do you keep a well-organized notebook with sections for } \\
\text { assignment, vocabulary, and lecture notes? }\end{array}$ & 36 & $40.91 \%$ \\
\hline $\begin{array}{l}\text { Do you keep a calendar for listing the due dates of major } \\
\text { assignments? }\end{array}$ & 42 & $47.73 \%$ \\
\hline Do you know what will be covered on each exam? & 45 & $51.14 \%$ \\
\hline Do you make specific preparations for exams? & 48 & $54.55 \%$ \\
\hline Do you study what you get wrong on a quiz or test? & 52 & $59.09 \%$ \\
\hline
\end{tabular}

From the table it could be seen that, from the first statement it has been noted that student respondents are spending less than haft the time in their study habits with $59.09 \%, 48.86 \%$ on the second statement stated that students respondents also spending less than the time of their study, third statement with $35.23 \%$ shows that students are almost always spent their time in their study, while $43.18 \%$ gathered in the fourth statement allowing students spent more than haft the time in their study. On the fifth statement $56.82 \%$ less than haft the time students spent their study, $60.23 \%$ of the students spent more than haft the time in their study on the sixth statement, 52.27\% more than haft of the time students spent their study habits on the seventh statement, $54.02 \%$ less than haft the time on the eight statement student spent their time of study, while on the ninth statements $40.02 \%$ of the students spent almost never in their study, $47.73 \%$ of the students spent less than haft the time in their study on the tenth statement, $51.14 \%$ of the students answers almost always spent in their study on the eleventh statement, on the twelfth statement students spent their study habits with 54.55\% almost always and on the last statement student spent their time in their study as more than haft the time with 59.09\%. It can be implied that study habits of the students respondents are basically depends on their schedule of activities, meetings and other extracurricular events of the University. 
Table 6. Questionnaire \# 2 Study Habits of the Respondents For the study habits of the students respondents, each statement will be rated by "yes" or "no".

\begin{tabular}{|l|l|l|}
\hline Statements/Indicator & Frequency & Percent (N=88) \\
\hline I am trying to be a more efficient and effective learner & 87 & $98.86 \%$ \\
\hline $\begin{array}{l}\text { I am aware of the benefits of asking good questions as I read, take notes, } \\
\text { and study. }\end{array}$ & 84 & $95.45 \%$ \\
\hline $\begin{array}{l}\text { I believe that my intelligence is revealed more in the questions I ask than } \\
\text { in the answer I give. }\end{array}$ & 78 & $88.64 \%$ \\
\hline $\begin{array}{l}\text { I believe most lectures can be viewed as a series of questions and } \\
\text { answers. }\end{array}$ & 69 & $78.41 \%$ \\
\hline $\begin{array}{l}\text { I know how to spend less time studying by concentrating on developing } \\
\text { practice test questions. }\end{array}$ & 42 & $47.73 \%$ \\
\hline I am able to use lecture notes for exam preparation. & 66 & $75.00 \%$ \\
\hline I usually look for possible test questions and answers as I read. & 58 & $65.91 \%$ \\
\hline I usually study as though I am practicing to take a test. & 60 & $68.18 \%$ \\
\hline
\end{tabular}

* Statement with "no" responses are areas where the learner may need to improve study habits.

It can be gleaned on the table 6 second questionnaire of students study habits, stated that majority of the student respondents answers "yes" in all statements with $98.86 \%$ which is the highest percentage answer of the students in their study habits on the first statement. It can be implied that even some of the students are working still they have time to study and involve in any students organizations. It is also an advantage to the students who are working and involve in an organization so that they will make good standing in their study. and graduated with good identity and honors.

\section{Academic Performance}

On academic performance student respondents answers poor, fair, good, very good and excellent to determine their academic performance.

Table 7. Academic Performance

\begin{tabular}{|l|l|l|}
\hline Statements/Indicator & Frequency & Percent $\mathbf{( N = 8 8 )}$ \\
\hline Mid-term test & 58 & $65.91 \%$ \\
\hline Take-home course work & 60 & $68.18 \%$ \\
\hline Previous semester exam & 58 & $65.91 \%$ \\
\hline Compulsory courses & 62 & $70.45 \%$ \\
\hline Optional courses & 54 & $61.36 \%$ \\
\hline
\end{tabular}

Table 7 on the academic performance of the student respondents reveals that most of the students answer "Good". It can be implied that students who are involved in extracurricular activities like joining the organization could also be a crucial in attaining good scholastic standing. It is important that these students must have their proper time management so that they not overlook some of their duties as students in the University.

\section{Conclusion}

As gleaned from the findings of the study, that females are dominating the involvement of students in an organization, most of the respondents are coming from Bachelor of Secondary Education they roman catholic and majority of them are first year college, students who are members of the organization in the university are supported with scholarship and the organization of the university are registered by the Student Affairs Office and most of this organization are academic in nature, student organization lasted for years because student respondents even though they working student but still they are active in their involvement in the organization, study habits of the students respondents are basically depends on their schedule of activities, meetings and other extracurricular events of the University, some of the students are working but still they have time to study and involve in any students organizations.

\section{Recommendation}

Based on the conclusions generated, the following recommendation are hereby proposed: First, students organization in the University should invite male members and other religious affiliations to increase their involvement in the organizations of the University, Second, student affairs office of the university must lower down their guidelines and criteria in their scholarship program so that students who have less access for high education can avail their programs. Third, student organization must not focus on academic only because student talents are diverse and others are good in other aspects i.e. sports, community awareness and others. Fourth, working student who are involve in active organization should be given less responsibilities so that they will have time to study and work. Fifth, student organizations schedule of activities must fall during free time and not during examinations. and Lastly, student organizations must involve all students in the university to 
attain cohesiveness of all students in the university follow guidelines and specifications from the student affairs office for harmonious conduct of their student activities in the University.

\section{References}

[1]. Blumler, J. G. "The social character of media gratifications". In K. E. Rosengren, L. A. Wenner, \& P. Palmgreen (Eds.),1985

[2]. Carey, J. W., \& Kreiling, A. L. "Popular culture and uses and gratifications": Notes toward an accommodation. In J. G. Blumler \& E. Katz (Eds.), The uses of mass communications: Current perspectives on gratifications research (pp. 225-248). Beverly Hills, CA: Sage. 1974

[3]. Bantz, C. R. "Exploring uses and gratifications": A comparison of reported uses of television and reported uses of favorite program type. Communication Research, 9, 352-379. 1982

[4]. https://en.wikipedia.org/wiki/Uses_and_gratifications_theory

[5]. West, Richard; Turner, Lynn. "Introducing Communication Theory". McGraw Hill, 2007

[6]. Palmgreen, P; L. Wenner; K. Rosengren. "Uses and gratifications research: The past ten years.". Media gratifications research, 1985

[7]. http://www4.ncsu.edu/ amgutsch/Ruggiero.pdf 